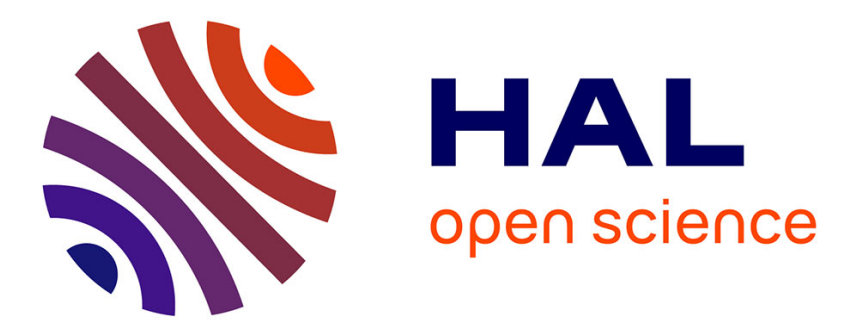

\title{
Synthesis, characterization and X-ray crystal structures of chiral ferrocene-containing $\beta$-diketones
}

Guillermo Ahumada, Thierry Roisnel, Sourisak Sinbandhit, Carolina Manzur, David Carrillo, Jean-René Hamon

\section{- To cite this version:}

Guillermo Ahumada, Thierry Roisnel, Sourisak Sinbandhit, Carolina Manzur, David Carrillo, et al.. Synthesis, characterization and X-ray crystal structures of chiral ferrocene-containing $\beta$-diketones. Journal of Organometallic Chemistry, 2013, 737, pp.1-6. 10.1016/j.jorganchem.2013.03.032 . hal00843023

\section{HAL Id: hal-00843023}

\section{https://hal-univ-rennes1.archives-ouvertes.fr/hal-00843023}

Submitted on 10 Jul 2013

HAL is a multi-disciplinary open access archive for the deposit and dissemination of scientific research documents, whether they are published or not. The documents may come from teaching and research institutions in France or abroad, or from public or private research centers.
L'archive ouverte pluridisciplinaire HAL, est destinée au dépôt et à la diffusion de documents scientifiques de niveau recherche, publiés ou non, émanant des établissements d'enseignement et de recherche français ou étrangers, des laboratoires publics ou privés. 


\title{
Synthesis, characterization and X-ray crystal structures of chiral ferrocene-containing $\beta$-diketones
}

\author{
Guillermo Ahumada $^{a}$, Thierry Roisnel ${ }^{b}$, Sourisak Sinbandhit ${ }^{c}$, \\ Carolina Manzur ${ }^{\mathrm{a}}$ * David Carrillo ${ }^{\mathrm{a}}$, Jean-René Hamon ${ }^{\mathrm{b} *}$
}

a Laboratorio de Química Inorgánica, Instituto de Química, Pontificia Universidad Católica de Valparaíso, Campus Curauma, Avenida Universidad 330, Valparaíso, Chile

b UMR 6226 «Institut des Sciences Chimiques de Rennes», CNRS-Université de Rennes 1, Campus de Beaulieu, 35042 Rennes Cedex, France

c Centre Régional de Mesures Physiques de l'Ouest, Université de Rennes 1, Campus de Beaulieu, 35042 Rennes Cedex, France

Corresponding authors. Phone: 563222749 32, E-mail address: cmanzur@ucv.cl (C. Manzur);Phone: 332232359 58, E-mail address: jean-rene.hamon@univ-rennes1.fr (J.-R. Hamon). 


\begin{abstract}
Three new chiral ferrocene-containing $\beta$-diketones have been synthesized by reacting 1-ferrocenyl ethanol with the corresponding 1,3-diketone reagent $\mathrm{MeCOCH}_{2} \mathrm{COR}(\mathrm{R}=\mathrm{Me}$, 4- $\left.\mathrm{C}_{6} \mathrm{H}_{4} \mathrm{OMe}, \mathrm{Fc} ; \mathrm{Fc}=\left(\eta^{5}-\mathrm{C}_{5} \mathrm{H}_{5}\right) \mathrm{Fe}\left(\eta^{5}-\mathrm{C}_{5} \mathrm{H}_{4}\right)\right)$, using cerium(IV) ammonium nitrate $(\mathrm{CAN})$ mediated C-C bond formation. These compounds identified as 3-(1-ferrocenylethyl)-pentane2,4-dione (1), 1-(4-methoxyphenyl)-2-(1-ferrocenylethyl)-butane-1,3-dione (2), and 1ferrocenyl-2-(1-ferrocenylethyl)-butane-1,3-dione (3), have been isolated as air and thermally stable microcrystalline solids in 79,63 and 44\% yields, respectively. Compounds 2 and 3 were formed in 63:37 and 88:12 diastereomeric ratios, respectively. They have been fully characterized by elemental analyses, FT-IR spectra, mass spectrometry, and their complete assignments have been conducted using 2D NMR experiments. In addition, their molecular identity and geometry have been confirmed by single-crystal X-ray diffraction, and both solution and solid state measurements have shown that the three complexes exist solely as their diketo tautomers.
\end{abstract}

Keywords: ferrocenyl-derivatives; chiral $\beta$-diketones; C-C coupling; X-ray structures 


\section{Introduction}

In the past decades, $\beta$-diketones have attracted a growing interest in the synthesis of biologically active heterocyclic compounds such as diazepines, benzodiazepines, pyrazoles, isoxazoles, imidazoles and benzymidazoles [1,2]. $\beta$-diketones exhibit also a variety of pharmacological activities like antibacterial, antiviral and systematic insecticidal agents and have also shown potential antioxidant and antitumor activities [3]. Likewise, this class of precursor have extensively been used in the synthesis of asymmetric tridentate Schiff base ligands through the imine and amine nitrogen atoms and the carbonyl oxygen, also called "half unit" [4], via mono-condensation with aliphatic and aromatic diamines [4-6], as well as for the design of transition metal complexes [7]. In most $\beta$-diketones, the substituents on the central carbon are hydrogen atoms or classical organic groups [1,8] although some examples containing achiral [9] and chiral organometallic substituents are known [10,11].

Cerium ammonium nitrate (CAN) has emerged as a versatile reagent in a variety of synthetic transformations where the chemistry of cerium(IV) dominates through the oxidation of organic molecules via radical pathway [12]. This compound is a convenient and excellent reagent for effecting a wide variety of synthetic transformations [13]; its solubility in organic solvents such as methanol and acetonitrile, its low toxicity, its ease of handling, and its high reactivity have contributed to a general acceptance as a reagent of choice for one-electron oxidations [12]. Today, the application of the radical methodology in organic synthesis has evolved as a prominent tool in this area [14].

For several years, we have been interested in the synthesis of ferrocenyl-containing diketones as starting materials for the preparation of assymmetric Schiff base complexes $[6,15]$. In our previous work, both the metalloligand and its derivatized multinuclear compounds presented the ferrocenyl unit always bounded to the carbonyl atom of the 1,3dione entity. Thus, in pursuit of our research work aimed at extending the scope of acyclic Schiff base metalloligands, we decided to synthetize new $\beta$-diketones functionalized at the central carbon with the chiral 1-ferrocenylethyl moiety $\left[\mathrm{FcCH}\left(\mathrm{CH}_{3}\right)\right]\left(\mathrm{Fc}=\left(\eta^{5}-\mathrm{C}_{5} \mathrm{H}_{5}\right) \mathrm{Fe}\left(\eta^{5}-\right.\right.$ $\left.\mathrm{C}_{5} \mathrm{H}_{4}\right)$ ), using the $\mathrm{CAN}$-mediated $\mathrm{C}-\mathrm{C}$ bond formation between ferrocenylethanol and the apropriate 1,3-diketones. Herein, we report on the synthesis, the full analytical and spectroscopic characterization, and the crystal and molecular structures of such three chiral organometallic $\beta$-diketones. 


\section{Experimental}

\subsection{General Experimental Methods}

All manipulations were carried out under dinitrogen atmosphere using standard Schlenk techniques. Reagents were purchased from commercial sources and used as received. 1-ferrocenyl ethanol [16], 1-ferrocenyl-1,3-butanedione [15a] and 1-(4methoxyphenyl)butane-1,3-dione [17] were synthesized according to the procedures reported in the literature. Melting points were measured in evacuated capillaries and were not corrected. The solid FT-IR spectra were recorded from $\mathrm{KBr}$ disks on a Perkin Elmer model 1600 spectrophotometer in the range $4000-450 \mathrm{~cm}^{-1} .{ }^{1} \mathrm{H}$ and ${ }^{13} \mathrm{C}$ NMR spectra were recorded on a multinuclear Bruker AC 400 and Bruker DPX 500 spectrometers using $\mathrm{CDCl}_{3}$ as solvent. Chemical shifts are reported in ppm relative to tetramethylsilane with the residual solvent proton and carbon resonances used as internal standards. Coupling constants ( $\mathrm{J}$ ) are reported in Hertz $(\mathrm{Hz})$, and integrations are reported as number of protons. High resolution electrospray ionization mass spectra (HRMS ESI) were obtained at the Centre Régional de Mesures Physiques de l'Ouest (CRMPO, Rennes) on a Bruker Q-Tof 2 spectrometer. Microanalyses were conducted on a Thermo-FINNIGAN Flash EA 1112 CHNS/O analyzer by the Microanalytical Service of the CRMPO at the University of Rennes 1, France. Cyclic voltammetry (CV) measurements were performed using a Radiometer Analytical model PGZ 100 all-in one potentiostat, using a three-electrode CEMM with glassy carbon working, $\mathrm{Ag} / \mathrm{AgCl}$ reference and platinum wire auxiliary electrodes. The ferrocene/ferrocenium $\left(\mathrm{FcH}^{0 /+}\right)$ couple was located at $E_{1 / 2}=0.510 \mathrm{~V}$, where $E_{1 / 2}$ was calculated from the average of the oxidation and reduction peak potentials.

\subsection{Synthesis of 3-(1-ferrocenylethyl)-pentane-2,4-dione (1)}

In a Schlenk tube, $0.70 \mathrm{~g}(3.0 \mathrm{mmol})$ of 1 -ferrocenyl ethanol and $0.30 \mathrm{~mL}(3.0 \mathrm{mmol})$ of 2,4-pentanedione were dissolved in $8 \mathrm{~mL}$ of acetonitrile at room temperature (r.t.). After 5 min of stirring, $0.082 \mathrm{~g}(0.15 \mathrm{mmol})$ of cerium(IV) ammonium nitrate (CAN) (5\% molar) were added. The reaction mixture was stirred for $30 \mathrm{~min}$. and then evaporated under reduced pressure. The solid residue was mixed with $5 \mathrm{~mL}$ of water and extracted with $10 \mathrm{~mL}$ of diethyl ether. The organic phase was then dried over $\mathrm{MgSO}_{4}$, filtered off and evaporated under reduced pressure. The crude solid was chromatographed on silica gel using hexane:ethyl acetate $(8: 2 \mathrm{v} / \mathrm{v})$ to give $\mathbf{1}$ as a yellow solid. Recrystallization by slow evaporation of a saturated solution of diethyl ether at r.t. for 2 days provided $0.735 \mathrm{~g}$ (2.36 mmol, 79\%). Suitable single crystals for the X-ray diffraction study were selected from this 
crop. M.p.: $81^{\circ} \mathrm{C}$ (dec). Anal. calcd for $\mathrm{C}_{17} \mathrm{H}_{20} \mathrm{O}_{2} \mathrm{Fe}\left(312.18 \mathrm{~g} \mathrm{~mol}^{-1}\right)$ : C, 65.40; H, 6.46. Found: C, 65.26; H, 6.47\%. IR (KBr, cm $\left.{ }^{-1}\right)$ : 3097(w) v(C-H arom); 2994(m), 2977(m), 2949(m), 2923(m), 2852(m) v(C-H aliph); 1722(vs), 1700(vs) v(C=O). ${ }^{1} \mathrm{H}$ NMR (400 MHz, $\left.\mathrm{CDCl}_{3}\right): 1.32\left(\mathrm{~d}, 3 \mathrm{H},{ }^{3} J_{\mathrm{H}, \mathrm{H}}=6.8 \mathrm{~Hz}, \mathrm{CHCH}_{3}\right), 1.86\left(\mathrm{~s}, 3 \mathrm{H}, \mathrm{COCH}_{3}\right), 2.11\left(\mathrm{~s}, 3 \mathrm{H}, \mathrm{COCH}_{3}\right)$, $3.32\left(\mathrm{dq}, 1 \mathrm{H},{ }^{3} J_{\mathrm{H}, \mathrm{H}}=6.8\right.$ and $\left.10.0 \mathrm{~Hz}, \mathrm{CHCH}_{3}\right), 3.57\left(\mathrm{~d}, 1 \mathrm{H},{ }^{3} J_{\mathrm{H}, \mathrm{H}}=10.0 \mathrm{~Hz}, \mathrm{CH}\right), 3.99(\mathrm{~m}$, $1 \mathrm{H}, \mathrm{H}_{\alpha} \mathrm{C}_{5} \mathrm{H}_{4}$ ), 4.02 (br s, $1 \mathrm{H}, \mathrm{H}_{\alpha}, \mathrm{C}_{5} \mathrm{H}_{4}$ ), 4.07 (br s, $1 \mathrm{H}, \mathrm{H}_{\beta} \mathrm{C}_{5} \mathrm{H}_{4}$ ), 4.11 (br s, $1 \mathrm{H}, \mathrm{H}_{\beta}$, $\left.\mathrm{C}_{5} \mathrm{H}_{4}\right), 4.13\left(\mathrm{~s}, 5 \mathrm{H}, \mathrm{C}_{5} \mathrm{H}_{5}\right) .{ }^{13} \mathrm{C}\left\{{ }^{1} \mathrm{H}\right\} \mathrm{NMR}\left(100 \mathrm{MHz}, \mathrm{CDCl}_{3}\right): 18.30\left(\mathrm{CHCH}_{3}\right), 29.35$ and $31.95\left(\mathrm{COCH}_{3}\right), 34.64\left(\mathrm{CHCH}_{3}\right), 65.19\left(\mathrm{C}_{\alpha}, \mathrm{C}_{5} \mathrm{H}_{4}\right), 67.49\left(\mathrm{C}_{\beta} \mathrm{C}_{5} \mathrm{H}_{4}\right), 67.63\left(\mathrm{C}_{\beta}, \mathrm{C}_{5} \mathrm{H}_{4}\right), 68.58$ $\left(\mathrm{C}_{\alpha} \mathrm{C}_{5} \mathrm{H}_{4}\right), 68.64\left(\mathrm{C}_{5} \mathrm{H}_{5}\right), 77.21(\mathrm{CH}), 91.49\left(\mathrm{C}_{\mathrm{ipso}} \mathrm{C}_{5} \mathrm{H}_{4}\right), 203.43$ and $204.49\left(\mathrm{COCH}_{3}\right) . \mathrm{CV}$ : $\mathrm{E}_{1 / 2}=517 \mathrm{mV}\left(\Delta \mathrm{E}_{\mathrm{p}}=134 \mathrm{mV}\right)$.

\subsection{Synthesis of 1-(4-methoxyphenyl)-2-(1-ferrocenylethyl)-butane-1,3-dione (2)}

In a Schlenk tube, $0.570 \mathrm{~g}(2.46 \mathrm{mmol})$ of 1-ferrocenyl ethanol and $0.473 \mathrm{~g}(2.46$ mmol) of 1-(4-methoxyphenyl)butane-1,3-dione were dissolved in $8.0 \mathrm{~mL}$ of acetonitrile at r.t. and stirred for $5 \mathrm{~min}$. Then, $0.067 \mathrm{~g}(0.12 \mathrm{mmol})$ of CAN (5\% molar) was added, and the reaction mixture stirred for $4 \mathrm{~h}$. The volatils were evaporated under reduced pressure, the solid residue was mixed with $5 \mathrm{~mL}$ of water and extracted with $10 \mathrm{~mL}$ of diethyl ether. The organic phase was dried over $\mathrm{MgSO}_{4}$, filtered off and evaporated under reduced pressure. The residue obtained was chromatographed on silica gel using hexane:ethyl acetate $(8: 2 \mathrm{v} / \mathrm{v})$ to give 2 as a yellow solid. Recrystallization by slow evaporation of a saturated diethyl ether solution at r.t. for 2 days provided 0,628 g (1.55 mmol, 63\%). Suitable single crystals for Xray diffraction study were selected from this crop. M.p.: 89-90 ${ }^{\circ} \mathrm{C}$. Anal. Calcd for $\mathrm{C}_{23} \mathrm{H}_{24} \mathrm{FeO}_{3}$ (404.27 $\mathrm{g} \mathrm{mol}^{-1}$ ): C, 68.33; H, 5.98. Found: C, 68.62; H, 5.70 \%. HRMS ESI ${ }^{+} \mathrm{m} / z$ calcd For $\mathrm{C}_{23} \mathrm{H}_{24} \mathrm{FeO}_{3}$ : 404.10748, Found: 404.1071. IR (KBr, $\left.\mathrm{cm}^{-1}\right)$ : 3090 (w) v(C-H arom); 2994(w), 2969(w), 2936(w) v(C-H aliph); 1709(vs), 1672(vs) v(C=O). ${ }^{1} \mathrm{H}$ NMR (400 MHz, $\left.\mathrm{CDCl}_{3}\right)$, major diastereomer $(63 \%) 1.33\left(\mathrm{~d},{ }^{3} J_{\mathrm{H}, \mathrm{H}}=6.8 \mathrm{~Hz}, \mathrm{CHCH}_{3}\right), 1.94\left(\mathrm{~s}, \mathrm{COCH}_{3}\right), 3.58\left(\mathrm{dq},{ }^{3} J_{\mathrm{H}, \mathrm{H}}\right.$ $=6.8$ and $\left.9.2 \mathrm{~Hz}, \mathrm{CHCH}_{3}\right), 3.85\left(\mathrm{~s}, \mathrm{OCH}_{3}\right), 4.02$ and $4.07\left(\alpha, \alpha^{\prime} \mathrm{C}_{5} \mathrm{H}_{4}\right), 4.09$ and $4.10(2 \mathrm{x} \mathrm{m}$, $\left.\mathrm{H}_{\beta, \beta}, \mathrm{C}_{5} \mathrm{H}_{4}\right), 4.14\left(\mathrm{~s}, \mathrm{C}_{5} \mathrm{H}_{5}\right), 4.38\left(\mathrm{~d},{ }^{3} J_{\mathrm{H}, \mathrm{H}}=9.2 \mathrm{~Hz}, \mathrm{CH}\right), 6.90\left(\mathrm{~d},{ }^{3} J_{\mathrm{H}, \mathrm{H}}=9.0 \mathrm{~Hz}, \mathrm{C}_{6} \mathrm{H}_{4}\right), 7.89$ $\left(\mathrm{d},{ }^{3} J_{\mathrm{H}, \mathrm{H}}=9.0 \mathrm{~Hz}, \mathrm{C}_{6} \mathrm{H}_{4}\right)$; minor diastereomer $(37 \%) 1.40\left(\mathrm{~d},{ }^{3} J_{\mathrm{H}, \mathrm{H}}=6.9 \mathrm{~Hz}, \mathrm{CHCH}_{3}\right), 2.15(\mathrm{~s}$, $\left.\mathrm{COCH}_{3}\right), 3.60\left(\mathrm{dq},{ }^{3} J_{\mathrm{H}, \mathrm{H}}=6.9\right.$ and $\left.10.2 \mathrm{~Hz}, \mathrm{CHCH}_{3}\right), 3.81\left(\mathrm{~s}, \mathrm{OCH}_{3}\right), 3.75$ and $3.95(2 \mathrm{x} \mathrm{m}$, $\left.\mathrm{H}_{\beta, \beta}, \mathrm{C}_{5} \mathrm{H}_{4}\right), 3.96\left(\mathrm{~m}, \mathrm{H}_{\alpha} \mathrm{C}_{5} \mathrm{H}_{4}\right), 3.97\left(\mathrm{~m}, \mathrm{H}_{\alpha}, \mathrm{C}_{5} \mathrm{H}_{4}\right), 4.10\left(\mathrm{~s}, \mathrm{C}_{5} \mathrm{H}_{5}\right), 4.35\left(\mathrm{~d},{ }^{3} J_{\mathrm{H}, \mathrm{H}}=10.2 \mathrm{~Hz}\right.$, $\mathrm{CH}), 6.82\left(\mathrm{~d},{ }^{3} J_{\mathrm{H}, \mathrm{H}}=9.0 \mathrm{~Hz}, \mathrm{C}_{6} \mathrm{H}_{4}\right), 7.75\left(\mathrm{~d},{ }^{3} J_{\mathrm{H}, \mathrm{H}}=9.0 \mathrm{~Hz}, \mathrm{C}_{6} \mathrm{H}_{4}\right) .{ }^{13} \mathrm{C}\left\{{ }^{1} \mathrm{H}\right\} \mathrm{NMR}(100 \mathrm{MHz}$, $\left.\mathrm{CDCl}_{3}\right)$ : major diastereomer (63\%) $18.79\left(\mathrm{CHCH}_{3}\right), 29.83\left(\mathrm{COCH}_{3}\right), 34.51\left(\mathrm{CHCH}_{3}\right), 55.53$ 
$\left(\mathrm{OCH}_{3}\right), 65.61\left(\mathrm{C}_{\alpha} \mathrm{C}_{5} \mathrm{H}_{4}\right), 67.38$ and $67.63\left(\mathrm{C}_{\beta, \beta}, \mathrm{C}_{5} \mathrm{H}_{4}\right), 68.51\left(\mathrm{C}_{\alpha}, \mathrm{C}_{5} \mathrm{H}_{4}\right), 68.61\left(\mathrm{C}_{5} \mathrm{H}_{5}\right)$, $71.02(\mathrm{CH}), 92.01\left(\mathrm{C}_{\mathrm{ipso}} \mathrm{C}_{5} \mathrm{H}_{4}\right), 113.94\left(\mathrm{C}_{6} \mathrm{H}_{4}\right), 131.03\left(\mathrm{C}_{6} \mathrm{H}_{4}\right), 130.30\left(\mathrm{C}_{\mathrm{ipso}}-\mathrm{C} \mathrm{C}_{6} \mathrm{H}_{4}\right), 163.95$ $\left(\mathrm{C}_{\mathrm{ipso}}-\mathrm{O} \mathrm{C}_{6} \mathrm{H}_{4}\right), 193.47\left(\mathrm{COC}_{6} \mathrm{H}_{4}\right), 203.75\left(\mathrm{COCH}_{3}\right)$; minor diastereomer $(37 \%) 18.20$ $\left(\mathrm{CHCH}_{3}\right), 27.97\left(\mathrm{COCH}_{3}\right), 34.35\left(\mathrm{CHCH}_{3}\right), 55.45\left(\mathrm{OCH}_{3}\right), 65.25\left(\mathrm{C}_{\alpha} \mathrm{C}_{5} \mathrm{H}_{4}\right), 67.21$ and 67.26 $\left(\mathrm{C}_{\beta, \beta}, \mathrm{C}_{5} \mathrm{H}_{4}\right), 68.55\left(\mathrm{C}_{5} \mathrm{H}_{5}\right), 68.99\left(\mathrm{C}_{\alpha}, \mathrm{C}_{5} \mathrm{H}_{4}\right), 72.04(\mathrm{CH}), 92.00\left(\mathrm{C}_{\mathrm{ipso}} \mathrm{C}_{5} \mathrm{H}_{4}\right), 113.73\left(\mathrm{C}_{6} \mathrm{H}_{4}\right)$, $130.47\left(\mathrm{C}_{\mathrm{ipso}}-\mathrm{C} \mathrm{C}_{6} \mathrm{H}_{4}\right), 130.92\left(\mathrm{C}_{6} \mathrm{H}_{4}\right), 163.71\left(\mathrm{C}_{\mathrm{ipso}}-\mathrm{OC}_{6} \mathrm{H}_{4}\right), 194.44\left(\mathrm{COC}_{6} \mathrm{H}_{4}\right), 203.67$ $\left(C \mathrm{OCH}_{3}\right) \cdot \mathrm{CV}: \mathrm{E}_{1 / 2}=504\left(\Delta \mathrm{E}_{\mathrm{p}}=243 \mathrm{mV}\right)$.

\subsection{Synthesis of 1-ferrocenyl-2-(1-ferrocenylethyl)-butane-1,3-dione (3)}

In a Schlenk tube, $0.70 \mathrm{~g}(3.0 \mathrm{mmol})$ of 1 -ferrocenyl ethanol and $0.81 \mathrm{~g}(3.0 \mathrm{mmol})$ of 1-ferrocenyl-1,3-butanedione were dissolved in $8.0 \mathrm{~mL}$ of acetonitrile at r.t., and stirred for 5 min; then, $0.082 \mathrm{~g}(0.15 \mathrm{mmol})$ of CAN (5\% molar) were added. The reaction mixture was stirred for $48 \mathrm{~h}$ and then evaporated under reduced pressure. The crude solid was mixed with $5 \mathrm{~mL}$ of water and extracted with $10 \mathrm{~mL}$ of diethyl ether. The organic solution was dried over $\mathrm{MgSO}_{4}$, filtered off and then evaporated under reduced pressure. The solid residue was washed with methanol until no coloration of solvent was observed, and dried under vacuum to afford $0.633 \mathrm{~g}(1.31 \mathrm{mmol}), 44 \%$ of $\mathbf{3}$ as a red solid. Suitable single crystals for X-ray diffraction study were obtained by slow evaporation of a saturated dichloromethane solution at r.t. for 3 days. M.p.: $150^{\circ}$ C. Anal. Calcd for $\mathrm{C}_{26} \mathrm{H}_{26} \mathrm{Fe}_{2} \mathrm{O}_{2}\left(482.19 \mathrm{~g} \mathrm{~mol}^{-1}\right): \mathrm{C}, 64.76 ; \mathrm{H}$, 5.44. Found: C, 64.78; H, $5.36 \%$. HRMS ESI ${ }^{+} \mathrm{m} / z$ calcd for $\mathrm{C}_{26} \mathrm{H}_{26} \mathrm{O}_{2}{ }^{56} \mathrm{Fe}_{2}$ : 482.06316, Found: $482.0628[\mathrm{M}]^{+}$. IR $\left(\mathrm{KBr}, \mathrm{cm}^{-1}\right): 3103$ (w) v(C-H Arom); 2967(w), 2933(w) v(C-H aliph); 1702(vs), 1661(vs) $v(\mathrm{C}=\mathrm{O})$. For the assignments of ${ }^{1} \mathrm{H}$ and ${ }^{13} \mathrm{C}$ NMR spectra of $\mathbf{3}$, $\mathrm{Fe} 1$ and $-\mathrm{Fe} 2$ refer to the $\left[\mathrm{FcCH}\left(\mathrm{CH}_{3}\right)-\right]$ and [FcCO-] fragments, respectively. ${ }^{1} \mathrm{H}$ NMR (400 $\left.\mathrm{MHz}, \mathrm{CDCl}_{3}\right)$ : major diastereomer $(88 \%) 1.37\left(\mathrm{~d},{ }^{3} \mathrm{~J}_{\mathrm{H}, \mathrm{H}}=7.0 \mathrm{~Hz}, \mathrm{CHCH}_{3}\right), 2.20\left(\mathrm{~s}, \mathrm{COCH}_{3}\right)$, $3.54\left(\mathrm{dq},{ }^{3} J_{\mathrm{H}, \mathrm{H}}=7.0\right.$ and $\left.10.7 \mathrm{~Hz}, \mathrm{CHCH}_{3}\right), 3.74\left(\mathrm{~d},{ }^{3} J_{\mathrm{H}, \mathrm{H}}=10.7 \mathrm{~Hz}, \mathrm{CH}\right), 3.97\left(\mathrm{~s}, \mathrm{C}_{5} \mathrm{H}_{5}-\mathrm{Fe} 2\right)$, 3.99 (m, $\left.\mathrm{H}_{\beta} \mathrm{C}_{5} \mathrm{H}_{4}-\mathrm{Fe} 1\right), 4.04$ (m, $\left.\mathrm{H}_{\beta}, \mathrm{C}_{5} \mathrm{H}_{4}-\mathrm{Fe} 1\right), 4.05$ (m, $\left.\mathrm{H}_{\alpha} \mathrm{C}_{5} \mathrm{H}_{4}-\mathrm{Fe} 1\right), 4.13$ (s, $\left.\mathrm{C}_{5} \mathrm{H}_{5}-\mathrm{Fe} 1\right)$, $4.18\left(\mathrm{~m}, \mathrm{H}_{\alpha}, \mathrm{C}_{5} \mathrm{H}_{4}-\mathrm{Fe} 1\right)$, 4.41, 4.44, 4.51 and 4.67 (4 x m, $\left.\mathrm{H}_{\alpha, \alpha}, \beta, \beta, \mathrm{C}_{5} \mathrm{H}_{4}-\mathrm{Fe} 2\right) .{ }^{13} \mathrm{C}\left\{{ }^{1} \mathrm{H}\right\} \mathrm{NMR}$ (125 MHz, $\left.\mathrm{CDCl}_{3}\right)$ : major diastereomer (88\%) $18.10\left(\mathrm{CHCH}_{3}\right), 26.79\left(\mathrm{COCH}_{3}\right), 33.59$ $\left(\mathrm{CHCH}_{3}\right), 65.25\left(\mathrm{C}_{\alpha} \mathrm{C}_{5} \mathrm{H}_{4}-\mathrm{Fe} 1\right), 67.25\left(\mathrm{C}_{\beta} \mathrm{C}_{5} \mathrm{H}_{4}-\mathrm{Fe} 1\right), 67.50\left(\mathrm{C}_{\beta}, \mathrm{C}_{5} \mathrm{H}_{4}-\mathrm{Fe} 1\right), 68.62\left(\mathrm{C}_{5} \mathrm{H}_{5^{-}}\right.$ $\mathrm{Fe} 1), 69.54$ and $69.59\left(\mathrm{C}_{\alpha, \alpha}, \mathrm{C}_{5} \mathrm{H}_{4}-\mathrm{Fe} 2\right), 69.75\left(\mathrm{C}_{5} \mathrm{H}_{5}-\mathrm{Fe} 2\right), 69.94\left(\mathrm{C}_{\alpha}, \mathrm{C}_{5} \mathrm{H}_{4}-\mathrm{Fe} 1\right), 72.54$ and $72.78\left(\mathrm{C}_{\beta, \beta}, \mathrm{C}_{5} \mathrm{H}_{4}-\mathrm{Fe} 2\right), 75.07(\mathrm{CH}), 80.01\left(\mathrm{C}_{\mathrm{ipso}} \mathrm{C}_{5} \mathrm{H}_{4}-\mathrm{Fe} 2\right), 92.25\left(\mathrm{C}_{\mathrm{ipso}} \mathrm{C}_{5} \mathrm{H}_{4}-\mathrm{Fe} 1\right), 199.14$ (CO-Fc2), $204.07\left(\mathrm{COCH}_{3}\right) . \mathrm{CV}: \mathrm{E}_{1 / 2}=505 \mathrm{mV}\left(\Delta \mathrm{E}_{\mathrm{p}}=103 \mathrm{mV}\right), \mathrm{E}_{1 / 2}=803 \mathrm{mV}\left(\Delta \mathrm{E}_{\mathrm{p}}=121\right.$ $\mathrm{mV})$. 


\subsection{Crystal structure determinations}

X-ray data for single crystals of complexes 1-3, obtained as described above, were collected at 150(2) $\mathrm{K}$ on a Bruker APEXII AXS diffractometer, equipped with a CCD detector, using Mo-K $\alpha$ radiation $(\lambda=0.71073 \AA)$. For each compound, a crystal of appropriate size was coated in Paratone-N oil and mounted on a Kaptan loop. The loop was transferred to the diffractometer, centered in the beam, and cooled by a nitrogen flow lowtemperature apparatus that had been previously calibrated by a thermocouple placed at the same position as the crystal. The structures were solved by direct methods using SIR97 program [18], and then refined with full-matrix least-square methods based on $F^{2}$ (SHELXL97) [19], with the aid of WINGX program [20]. All non-hydrogen atoms were refined with anisotropic atomic displacement parameters. Hydrogen atoms were finally included in their calculated positions. The disorder observed for the carbon atoms of the two cyclopentadienyl rings in 3 was modelled using two positions per carbon with a fixed 0.5 occupancy for each carbon. A summary of the details about crystal data, collection parameters and refinement are documented in Table 1, and additional crystallographic details are in the CIF files. ORTEP and Ball-and-Stick views are generated using OLEX2 [21].

Table 1 Crystallographic data, details of data collection and structure refinement parameters for compounds 1-3

\begin{tabular}{llll}
\hline & \multicolumn{1}{c}{$\mathbf{1}$} & \multicolumn{1}{c}{$\mathbf{2}$} & \multicolumn{1}{c}{$\mathbf{3}$} \\
\hline Empirical Formula & $\mathrm{C}_{17} \mathrm{H}_{20} \mathrm{FeO}_{2}$ & $\mathrm{C}_{23} \mathrm{H}_{24} \mathrm{FeO}_{3}$ & $\mathrm{C}_{26} \mathrm{H}_{26} \mathrm{Fe}_{2} \mathrm{O}_{2}$ \\
Formula mass, g mol $^{-1}$ & 312.18 & 404.27 & 482.17 \\
Collection T, K & $150(2)$ & $150(2)$ & $150(2)$ \\
crystal system & Monoclinic & Monoclinic & Monoclinic \\
space group & $\mathrm{P} 2 / \mathrm{a}$ & $\mathrm{P} 2 / \mathrm{n}$ & $\mathrm{P} 2 / \mathrm{a}$ \\
$\mathrm{a}(\mathrm{A})$ & $10.6687(12)$ & $5.6433(4)$ & $11.6837(9)$ \\
$\mathrm{b}(\mathrm{A})$ & $7.7702(10)$ & $50.027(3)$ & $10.9004(10)$ \\
$\mathrm{c}(\tilde{\mathrm{A}})$ & $18.331(3)$ & $7.3947(5)$ & $16.3140(15)$ \\
$\beta\left({ }^{\circ}\right)$ & $105.896(5)$ & $111.116(4)$ & $94.480(4)$ \\
$\mathrm{V}\left(\check{\mathrm{A}}^{3}\right)$ & $1461.5(3)$ & $1947.5(2)$ & $2071.4(3)$ \\
$\mathrm{Z}$ & 4 & 4 & 4 \\
$\mathrm{D}_{\text {calcd }}\left(\mathrm{g} \mathrm{cm}^{-3}\right)$ & 1.419 & 1.379 & 1.546 \\
$\mathrm{Crystal}$ size $(\mathrm{mm})$ & $0.55 \times 0.36 \times$ & $0.51 \times 0.24 \times$ & $0.57 \times 0.13 \times$ \\
& 0.14 & 0.04 & 0.1 \\
$\mathrm{~F}(000)$ & 656 & 848 & 1000 \\
abs coeff $\left(\mathrm{mm}{ }^{-1}\right)$ & 1.030 & 0.794 & 1.421 \\
$\theta$ range $\left({ }^{\circ}\right)$ & 3.29 to 27.47 & 2.98 to 27.47 & 3.13 to 27.39 \\
range h,k, & $-13 / 13,-9 / 9,-$ & $-6 / 7,-64 / 64,-$ & $-13 / 15,-$ \\
& $23 / 23$ & $9 / 9$ & $12 / 14,-21 / 13$ \\
No. total refl. & 10382 & 15381 & 13698 \\
No. unique refl. & 3313 & 4408 & 4645
\end{tabular}




\begin{tabular}{llll} 
Comp. to $\theta_{\max }(\%)$ & 99.4 & 98.6 & 98.8 \\
Max/min transmission & $0.866 / 0.682$ & $0.969 / 0.780$ & $0.868 / 0.717$ \\
Data/Restraints/Parameters & $3313 / 0 / 184$ & $4408 / 0 / 223$ & $4645 / 0 / 252$ \\
Final R & $\mathrm{R}_{1}=0.0317$ & $\mathrm{R}_{1}=0.1255$ & $\mathrm{R}_{1}=0.0394$ \\
{$[\mathrm{I}>2 \sigma(\mathrm{I})]$} & $\mathrm{wR}_{2}=0.0745$ & $\mathrm{wR}_{2}=0.2479$ & $\mathrm{wR}_{2}=0.0936$ \\
$\mathrm{R}$ indices (all data) & $\mathrm{R}_{1}=0.0402$ & $\mathrm{R}_{1}=0.1600$ & $\mathrm{R}_{1}=0.0538$ \\
& $\mathrm{wR}_{2}=0.0784$ & $\mathrm{wR}_{2}=0.2613$ & $\mathrm{wR}_{2}=0.1012$ \\
Goodness of fit / $\mathrm{F}^{<}$ & 1.035 & 1.146 & 1.043 \\
Largest diff. Peak/hole & 0.346 and -0.395 & 0.990 and - & 0.644 and - \\
$\left(\mathrm{e}^{-3}\right)$ & & 1.906 & 0.502 \\
\hline
\end{tabular}

\section{Results and Discussion}

\subsection{Synthesis and characterization}

The syntheses of the organometallic $\beta$-diketones 1-3 have been carried out in acetonitrile, at room temperature for 0.5-48 h, by CAN-mediated oxidative $\mathrm{C}-\mathrm{C}$ coupling of 1 ferrocenyl ethanol with three different $\beta$-dicarbonyls compounds (Scheme 1), using the slightly modified procedure described by $\mathrm{Xu}$ et al. [11]. Compounds $\mathbf{1 - 3}$ were isolated as microcrystalline yellow (1 and 2) and red (3) solids in relatively good yields ranging from $79 \%$ for $\mathbf{1}$ to $63 \%$ for $\mathbf{2}$ and $44 \%$ for $\mathbf{3}$. This may suggest that the sterics play a significant role in the formation of the products as the yields decrease and the reaction times increase when the steric hindrance of the substituents of the starting diketone reagents increases. The electron donating ability of both 4-methoxyphenyl and ferrocenyl groups are known to be similar [22]. On the other hand, compound 1 was previously prepared in $90 \%$ yield by reaction of 1-ferrocenyl ethanol with 2,4-pentanedione, in water at $80{ }^{\circ} \mathrm{C}$ for $24 \mathrm{~h} \mathrm{[10]}$. Analytical, IR and NMR data are informative of the structure of 1, but no total assignments were achieved nor was the crystalline structure determined.

Scheme 1 Synthesis of 1-ferrocenylethyl containing $\beta$-diketones 1-3 
Complexes 1-3 are air and moisture insensitive, thermally stable and exhibit good solubility in non polar organic solvents such as hexane, diethyl ether, or dichloromethane. Their composition and identity were deduced from elemental analysis, mass spectrometry, FT-IR spectra, and mono- and two-dimensional NMR experiments (see Section 2). Additionally, the crystal and molecular structures of the three compounds were solved by Xray diffraction analysis.

The elemental analyses were consistent with the proposed formulae and the mass spectra of 2 and 3 showed a peak at $\mathrm{m} / \mathrm{z}=404$ and 482, respectively, that agree with the values expected for the radical cations $[\mathrm{M}]^{+}$.

The solid FT-IR spectra of compounds 1-3 exhibit similar features indicating analogous molecular structures. One of the weak $\mathrm{C}-\mathrm{H}$ stretching absorption bands in the $3100-3090 \mathrm{~cm}^{-1}$ range can be observed in the three compounds. On the other hand, the intense absorption bands observed in the $1720-1650 \mathrm{~cm}^{-1}$ range are due to the $v(\mathrm{C}=\mathrm{O})$ stretching mode of the carbonyl groups.

Compounds $\mathbf{2}$ and $\mathbf{3}$ are formed in 63:37 and 88:12 diasteroisomeric ratios, respectively. No attempts to separate the diastereomers were carried out. However, a complete assignment of the resonances for both diastereomers has been achieved for 2 whereas only the signals of the major diastereomer can be totally attributed for 3 .

The ${ }^{1} \mathrm{H}$ NMR spectra of complexes $\mathbf{1 - 3}$, recorded at $298 \mathrm{~K}$ in $\mathrm{CDCl}_{3}$, exhibited the expected resonance patterns consistent with the proposed structures. In each ${ }^{1} \mathrm{H}$ NMR spectrum, the $\left[\mathrm{Fc}-\mathrm{CH}\left(\mathrm{CH}_{3}\right)-\mathrm{CH}\right]$ framework is clearly identified with the following characteristic multiplicity scheme. The ferrocenyl fragment consists of a group of five signals of relative intensities $5: 1: 1: 1: 1$ in the range 3.75-4.20 ppm which are assigned to the five protons of the free $\mathrm{C}_{5} \mathrm{H}_{5}$ ring, and to the two pairs of diastereotopic $\mathrm{H}_{\alpha}, \mathrm{H}_{\alpha}$, and $\mathrm{H}_{\beta}, \mathrm{H}_{\beta}$, protons of the substituted cyclopentadienyl ring. The methyl and the two types of methyne (that of the ethyl unit and of the 1,3-dione portion) protons show up as doublet at $1.32<\delta<1.40 \mathrm{ppm}$, as double quarted in the range $3.32-3.60 \mathrm{ppm}$, and as doublet between 3.57 and $4.38 \mathrm{ppm}$, respectively. In addition, the diastereotopic acetyl groups of compound $\mathbf{1}$ appeared as two sharp singlets at 1.86 and $2.11 \mathrm{ppm}$ whereas in the spectrum of $\mathbf{2}$, the acetyl and anisyl protons of the major and minor diastereomers are observed as two sets of signals at 1.94/2.15 and 3.85/3.81, 6.90/6.82, 7.89/7.75 ppm, respectively. Lastly, the spectrum of the bimetallic derivative 3 displayed also a sharp singlet at $2.20 \mathrm{ppm}$ assigned to the acetyl protons, and a 
second group of five signals with integration ratio 5:1:1:1:1 due to the ferrocenoyl fragment attached to a chiral carbon center. The free $\mathrm{C}_{5} \mathrm{H}_{5}$ ring resonates as a sharp singlet at $3.97 \mathrm{ppm}$ whereas the four downfield shifted multiplets, in the range 4.41-4.67 ppm, are attributed to the two pairs of diastereotopic protons of the substituted ring. Interestingly, the ${ }^{1} \mathrm{H} N M R$ data showed that compounds 1-3 exist exclusively as their diketonic tautomeric form in solution. This behavior is in accordance with that reported for similar ferrocenylmethyl diketones for which the keto tautomer predominates in solution [9a].

Consistent with the proposed structures and clearly demonstrating their unsymmetrical nature, the decoupled ${ }^{13} \mathrm{C}\left\{{ }^{1} \mathrm{H}\right\}$ NMR spectra of complexes 1-3 exhibited for their common $\left[\mathrm{Fc}-\mathrm{CH}\left(\mathrm{CH}_{3}\right)-\mathrm{CH}\right]$ framework, the expected characteristic resonance pattern of 9 lines. They are assigned to: (i) the free $\mathrm{C}_{5}$ ring about $68.6 \mathrm{ppm}$, (ii) the two pairs of diastereotopic $\mathrm{C}_{\alpha, \alpha^{\prime}}$, and $\mathrm{C}_{\beta, \beta}$, carbons in the range 65.2-70.0 ppm, and the quaternary carbon at $92 \mathrm{ppm}$ of the substituted $\mathrm{C}_{5}$ moiety, (iii) the methyl, the exocyclic $\mathrm{CH}$ and the central 1,3-dione $\mathrm{CH}$ groups at around 18, 34 and between 71 and 77 ppm, respectively. In addition, the two diastereotopic acetyl groups of compound $\mathbf{1}$ are seen as two-fold two signals at 29.35/31.95 ppm $\left(\mathrm{CH}_{3}\right)$ and 203.43/204.49 ppm (C=O). In both compounds $\mathbf{2}$ and $\mathbf{3}$, the carbonyl carbon atom linked to the aromatic ring, showing up at 193.47:194.44 ppm for $\mathbf{2}$ and at 199.14 ppm for 3, is slightly upfield shifted $v s$ that of the acetyl group which appeared at 203.75:203.67 and 204.07 ppm, respectively, as a consequence of the ring current effect. As expected from the above mentioned proton NMR data of $\mathbf{3}$, the ferrocenyl part of the ferrocenoyl group gave rise to six resonances attributed to the free $\mathrm{C}_{5}$-ring and to the five magnetically inequivalent carbon nuclei of the substituted cyclopentadienyl ring.

\subsection{X-ray Crystallographic Studies}

Perspective views of compounds 1-3 with the atom labeling scheme are shown in Fig. 1, with selected bond distances and angles listed in Table 2. The molecular structures show that each compound consists of one 1-ferrocenylethyl group linked to the central carbon of a 1,3-diketone system. Complexes $\mathbf{1}$ and $\mathbf{3}$ cristallize in the monoclinic centrosymmetric space group $\mathrm{P} 2_{1 / \mathrm{a}}$, whereas the $\beta$-diketone 2 crystallizes in the monoclinic centrosymmetric space group $\mathrm{P} 2_{1 / \mathrm{n}}$, with in each case a single molecule in the asymmetric unit. Crystal cell of compound 1 contains both enantiomers with $(\mathrm{R})$ and $(\mathrm{S})$ configuration for the chiral $\mathrm{C}(11)$ carbon. In the crystal cells of compounds $\mathbf{2}$ and $\mathbf{3}$, the chiral carbon atoms $\mathrm{C}(11)$ and $\mathrm{C}(13)$ 
are found with the $(\mathrm{S}, \mathrm{S})$ and $(\mathrm{S}, \mathrm{R})$ configuration, respectively. Both diastereomeric forms are related by a symmetry plane with inversion of the configuration at each carbon.
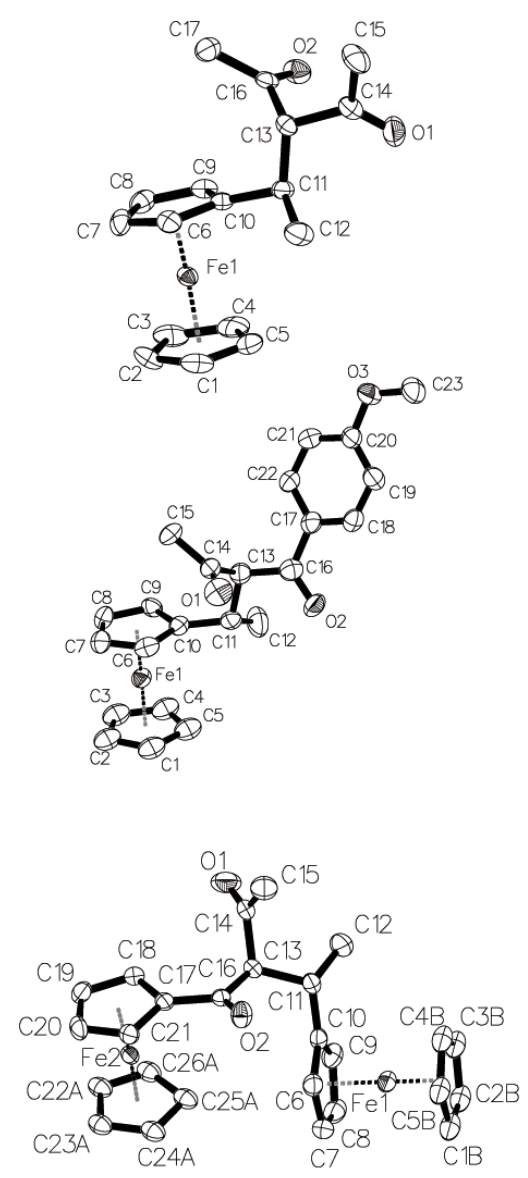

Fig. 1 Molecular structures of $\mathbf{1}$ (top), $\mathbf{2}$ (middle), and $\mathbf{3}$ (bottom) with the atom numbering schemes. Hydrogen atoms have been omitted for clarity. Thermal ellipsoids are drawn at $40 \%$ probability.

Table 2 Selected bond distances $(\AA)$ and angles $\left(^{\circ}\right)$ for compounds 1-3

\begin{tabular}{|c|c|c|c|}
\hline & 1 & 2 & 3 \\
\hline \multicolumn{4}{|c|}{ Bond distances } \\
\hline $\mathrm{C}(10)-\mathrm{C}(11)$ & $1.504(2)$ & $1.508(10)$ & $1.506(3)$ \\
\hline $\mathrm{C}(11)-\mathrm{C}(12)$ & $1.531(2)$ & $1.524(12)$ & $1.528(3)$ \\
\hline$C(11)-C(13)$ & $1.547(2)$ & $1.547(10)$ & $1.546(3)$ \\
\hline $\mathrm{C}(13)-\mathrm{C}(14)$ & $1.529(2)$ & $1.549(12)$ & $1.537(3)$ \\
\hline$C(13)-C(16)$ & $1.540(2)$ & $1.534(11)$ & $1.539(3)$ \\
\hline $\mathrm{C}(14)-\mathrm{O}(1)$ & $1.210(2)$ & $1.204(10)$ & $1.201(3)$ \\
\hline
\end{tabular}




\begin{tabular}{llll}
$\mathrm{C}(16)-\mathrm{O}(2)$ & $1.211(2)$ & $1.227(10)$ & $1.219(3)$ \\
$\mathrm{C}(16)-\mathrm{C}(17)$ & $1.502(2)$ & $1.501(11)$ & $1.469(3)$ \\
$\mathrm{Fe}(1)-\mathrm{C}(\mathrm{Cp})$ avg & 2.0433 & 2.0524 & 2.046 \\
$\mathrm{Fe}(1)-\mathrm{C}(\mathrm{Cp})$ avg & 2.0468 & 2.0504 & 2.047 \\
\hline \multicolumn{4}{c}{ Angles } \\
\hline $\mathrm{C}(10)-\mathrm{C}(11)-\mathrm{C}(13)$ & $110.63(13)$ & $108.6(6)$ & $110.57(19)$ \\
$\mathrm{C}(11)-\mathrm{C}(13)-\mathrm{C}(14)$ & $112.43(13)$ & $112.0(7)$ & $110.92(19)$ \\
$\mathrm{C}(11)-\mathrm{C}(13)-\mathrm{C}(16)$ & $110.15(13)$ & $111.4(6)$ & $113.34(19)$ \\
$\mathrm{C}(14)-\mathrm{C}(13)-\mathrm{C}(16)$ & $106.99(13)$ & $105.6(7)$ & $107.39(19)$ \\
$\mathrm{C}(13)-\mathrm{C}(14)-\mathrm{O}(1)$ & $122.00(15)$ & $119.8(8)$ & $120.4(2)$ \\
$\mathrm{C}(13)-\mathrm{C}(16)-\mathrm{O}(2)$ & $120.64(16)$ & $120.7(7)$ & $121.7(2)$ \\
\hline
\end{tabular}

Abbreviations: $\mathrm{Cp}=\mathrm{C}_{5} \mathrm{H}_{5}, \mathrm{Cp}^{\prime}=\mathrm{C}_{5} \mathrm{H}_{4}$.

For each compound, the ferrocenyl group with co-planar and eclipsed cyclopentadienyl rings features a linear sandwich structure with a typical $\left[\eta^{5}-\mathrm{Fe}-\eta^{5}\right]$ coordination mode. The iron atom is coordinated to the free and substituted cyclopentadienyl rings at a ring centroid-iron distances of 1.651/1.649 $\AA$ (for 1), 1.660/1.655 $\AA$ (for 2), 1.659/1.648 (Fe1) and 1.657/1.651 (Fe2) $\AA$ (for 3), with ring centroid-iron-ring centroid angle of $176.6^{\circ}$ (for $\mathbf{1}$ ), $179.1^{\circ}$ (for 2 ), 179.2 (Fe1) and $177.9^{\circ} \mathrm{Fe} 2$ ) (for 3 ), respectively, indicating that there is a $\mathrm{Fe}(\mathrm{II})$ oxidation state in each metallocene [23].

In agreement with FT-IR and NMR data (see Sections 2 and 3.1), the crystal structures confirm that the three complexes 1-3 exist solely as their diketo tautomer. The measured $\mathrm{C}(14)-\mathrm{O}(1)$ and $\mathrm{C}(16)-\mathrm{O}(2)$ bond lenghts (see Table 2) are typical of $\mathrm{C}=\mathrm{O}$ double bonds [24], as found for another structurally characteerized non-enolized 1,3-diketone [25]. Moreover, the $\mathrm{C}-\mathrm{C}$ bond distances $(>1.52 \AA)$ and angles $\left(\sim 110^{\circ}\right)$ around the central $\mathrm{C}(13)$ carbon are those expected for a $\mathrm{sp}^{3}$-hybridized carbon atom (Table 2).

On the other hand, within complex 3 the fragment $\mathrm{C}(17)-\mathrm{C}(16)-\mathrm{O}(2)$ is almost coplanar with the substituted cyclopentadienyl ring $\mathrm{C}(17) \cdots \mathrm{C}(21)$ with a dihedral angle of $12.8^{\circ}$. This is typical of the conformations observed in simple acyl ferrocenes Fc-COR [26]. Similarly in 2, the fragment $\mathrm{C}(17)-\mathrm{C}(16)-\mathrm{O}(2)$ is almost coplanar $\left(10.1^{\circ}\right)$ with the phenyl ring of the anisyl moiety.

Within the crystal structures of 1-3 there are a number of short intermolecular contacts. For instance, cyclopentadienyl-H $\cdots \pi$ interactions are observed for each compound (Table 3), whereas intermolecular $\mathrm{C}-\mathrm{H} \cdots \mathrm{O}$ hydrogen bonds (Table 4) generate a dimeric unit in compound $\mathbf{2}$ creating a plane of symmetry between the molecules, and a chain structure in complex 3 (Fig. 2). 

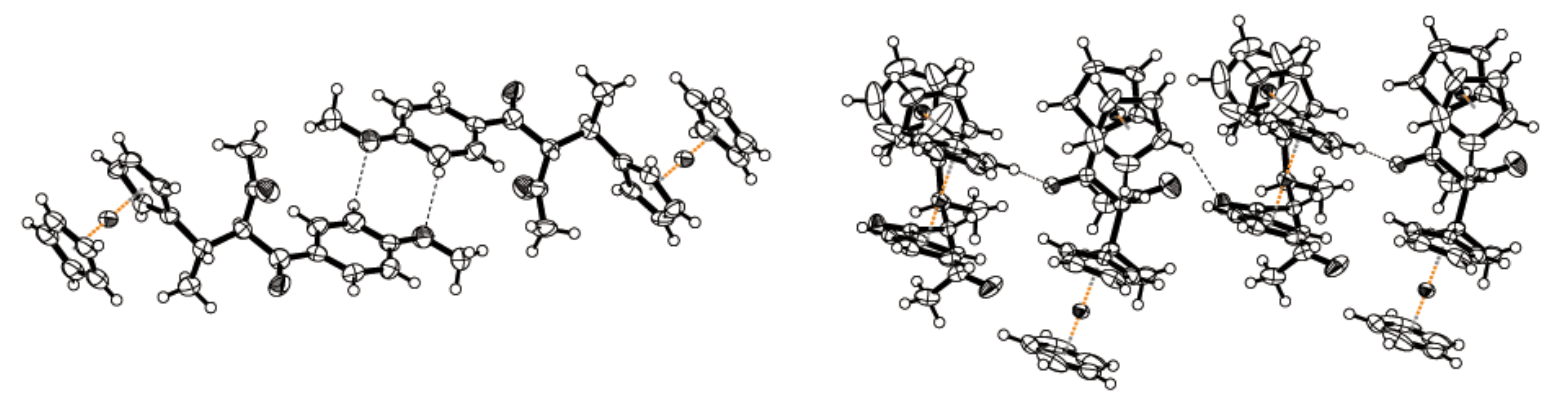

Fig. 2 Intermolecular hydrogen bond interactions forming a dimeric unit in 2 (left) and a chain structure in $\mathbf{3}$ (right).

Table 3 Cyclopentadienyl $-\mathrm{H} \cdots \pi$ Interactions

\begin{tabular}{clllll}
\hline Compd & $\mathrm{D}-\mathrm{H} \cdots \mathrm{A}$ & $\mathrm{D}-\mathrm{H}(\AA)$ & $\mathrm{H} \cdots \mathrm{A}(\AA)$ & $\mathrm{D} \cdots \mathrm{A}(\AA)$ & $\mathrm{D}-\mathrm{H} \cdots \mathrm{A}\left({ }^{\circ}\right)$ \\
\hline $\mathbf{1}$ & $\mathrm{C} 17-\mathrm{H} 17 \cdots \mathrm{Cg} 2^{\mathrm{i}}$ & 0.95 & 2.97 & $3.697(2)$ & 132 \\
$\mathbf{2}$ & $\mathrm{C} 15-\mathrm{H} 15 \mathrm{~B} \cdots \mathrm{Cg} 2^{\mathrm{i}}$ & 0.95 & 2.86 & $3.626(10)$ & 135 \\
& $\mathrm{C} 23-\mathrm{H} 23 \mathrm{C} \cdots \mathrm{Cg} 3^{\mathrm{ii}}$ & 0.95 & 2.75 & $3.626(10)$ & 149 \\
$\mathbf{3}$ & $\mathrm{C} 25 \mathrm{~B}-\mathrm{H} 25 \mathrm{~B} \cdots \mathrm{Cg} 3^{\mathrm{i}}$ & 0.95 & 2.67 & $3.594(3)$ & 164 \\
\hline
\end{tabular}

Symmetry Codes: (i) x,y,z; (ii) 2-x,-y,1-z

Table 4 Hydrogen Bonding interactions parameters

\begin{tabular}{clllll}
\hline Compd & $\mathrm{D}-\mathrm{H} \cdots \mathrm{A}$ & $\mathrm{D}-\mathrm{H}(\AA)$ & $\mathrm{H} \cdots \mathrm{A}(\AA)$ & $\mathrm{D} \cdots \mathrm{A}(\AA)$ & $\mathrm{D}-\mathrm{H} \cdots \mathrm{A}\left({ }^{\circ}\right)$ \\
\hline $\mathbf{2}$ & $\mathrm{C} 21-\mathrm{H} 21 \cdots \mathrm{O}^{\mathrm{ii}}$ & 0.95 & 2.67 & $3.594(3)$ & 164 \\
\hline $\mathbf{3}$ & $\mathrm{C} 26 \mathrm{~A}-\mathrm{H} 26 \mathrm{~A} \cdots \mathrm{O} 2^{\mathrm{i}}$ & 0.95 & 2.52 & 3.357 & 147 \\
\hline
\end{tabular}

Symmetry Codes: (i) -1/2+x,1/2-y,z; (ii) 3-x,-y,2-z

\subsection{Cyclic voltammetry}

The electrochemical features of compounds 1-3 were investigated by cyclic voltammetry in dichloromethane solution containing $0.1 \mathrm{M} n-\mathrm{Bu}_{4} \mathrm{NPF}_{6}$ as supporting electrolyte. All measurements were carried out in $10^{-3} \mathrm{M}$ solutions at room temperature in the potential range +1.5 to $-1.0 \mathrm{~V}$ with scan rate $100 \mathrm{mV} \mathrm{s}^{-1}$. Cyclic voltammograms $(\mathrm{CV})$ of solutions containing 1-3 show a chemically reversible oxidation process with current ratio $i_{\mathrm{pa}} / i_{\mathrm{pc}}$ equal to unity, at $E_{1 / 2}$ values identical, within the experimental errors, to that of the $\mathrm{FcH} / \mathrm{FcH}^{+}$couple $\left(E_{1 / 2}=0.510 \mathrm{~V}\right)$ taken as internal reference. The anodic to cathodic peak-topeak separations are similar to that observed for ferrocene under identical conditions, indicating that it is likely a one-electron oxidation of the 1-ferrocenylethyl entity to the respective ferrocenium species $\mathbf{1}^{+2+}$ and $\mathbf{3}^{+}$at the electrode. In addition, the $\mathrm{CV}$ of $\mathbf{3}$ exhibited a second reversible wave at $E_{1 / 2}=0.803 \mathrm{~V}$ attributable to the mono-electronic oxidation of the ferrocenoyl moiety. Such a strong positive shift $(0.293 \mathrm{~V})$ with respect to free ferrocene, is 
presumably due to the electron withdrawing effect of the cationic acylketone substituent. This value compares well with the $0.250 \mathrm{~V}$ vs $\mathrm{FcH} / \mathrm{FcH}^{+}$value found for acetylferrocene [27], for which the acetyl substituent is expected to be less electron withdrawing than the cationic diketonic group in $\mathbf{3}$.

\section{Conclusion}

In summary, we have described the successful preparation, using CAN-mediated C-C bond forming reaction, of three chiral ferrocene-containing $\beta$-diketones starting from 1ferrocenylethanol. The microcristalline compounds were isolated in raisonably good yields and were fully characterized by analytical and spectroscopic methods, including their total assignment using the 2D NMR technology, and by single crystal X-ray diffraction analysis. Additionally, both solution and solid state measurements have shown that the three complexes exist solely as their diketo tautomers. The potential applications of these chiral ferrocenecontaining 1,3-diketones as building blocks for the synthesis of new chiral Schiff bases and their corresponding transition metal complexes, as well as chiral diazepines are underway and will be described in future publications.

\section{Acknowledgments}

The authors thank Dr. P. Jehan (CRMPO, Rennes) for assistance with HRMS experiments. This research has been performed as part of the Chilean-French International Associated Laboratory for "'Inorganic Functional Materials"' (LIAMIF-CNRS N'836). Financial support from the Fondo Nacional de Desarrollo Científico y Tecnológico [FONDECYT (Chile), grant no. 1090310 (C.M. and D.C.)], the Vicerrectoría de Investigación y Estudios Avanzados, Pontificia Universidad Católica de Valparaíso, Chile (C.M. and D.C.), the CNRS and the Universite de Rennes 1 is gratefully acknowledged. G.A. Thanks the CONICYT (Chile) for support of a graduate fellowship.

\section{Appendix A. Supplementary material}

CCDC 922490 (for 1), 922491 (for 2), and 922492 (for 3) contain the supplementary crystallographic data for this paper. These data can be obtained free of charge from the Cambridge Crystallographic Data Centre via www.ccdc.cam.as.uk/data_request/cif.

\section{References}


[1] E.V. Shchegol'kov, Y.V. Burgart, O.G. Khudina, V.I. Saloutin, O.N. Chupakhin, Russ. Chem. Rev. 79 (2010) 31.

[2] (a) A.L. Baumstark, A. Choudhary, P.C. Vasquez, M. Dotrong, J. Heterocyclic Chem. 27 (1990) 291;

(b) A.P.West, Jr., D. Van Engen, R.A. Pascal, Jr., J. Org. Chem. 57 (1992) 784;

(c) C.P. Felix, N. Khatimi, A.J. Laurent, J. Org. Chem. 60 (1995) 3907;

(d) D. Kumar, S.P. Singh, Heterocycles 63 (2004) 145;

(e) M.A.P. Martins, S. Brondani, V.L. Leidens, D.C. Flores, S. Moura, N. Zanatta, M. Horner, A.F.C. Flores, Can. J. Chem. 83 (2005) 1171.

[3] (a) G.D. Diana, P.M. Carabateas, R.E. Johnson, G.L. Williams, F. Pancic, J.C. Collins, J. Med. Chem. 21 (1978) 889;

(b) A.V. Kel'in, Curr. Org. Chem.7 (2003) 1691;

(c) A.V. Kel'in, A. Maioli, Curr. Org. Chem. 7 (2003) 1855.

[4] (a) G. Cros, J.-P. Costes, C. R. Acad. Sci. Paris, Ser. Iic 294 (1982) 173;

(b) G. Bett, D.E. Fenton, J.R. Tate, Inorg. Chim. Acta 54 (1981) L101;

(c) J.-P. Costes, D.E. Fenton, J. Chem. Soc., Dalton Trans. (1983) 2235;

(d) J.-P. Costes, Polyhedron 6 (1987) 2169 and references cited therein.

[5] (a) P. Hu, L. Zhang, X. Zhu, X. Liu, L. Ji, Y. Chen, Polyhedron 8 (1989) 2459;

(b) A.D. Garnovskii, B.I. Kharixov, L.M. Blanco, D.A. Garnovskii, A.S. Burlov, I.S. Vasilchenko, G.I. Bondarenko, J. Coord. Chem. 46 (1999) 365.

[6] (a) M. Fuentealba, A. Trujillo, J.-R. Hamon, D. Carrillo, C. Manzur, J. Mol. Struct. 881 (2008) 76;

(b) M. Fuentealba, J.-R. Hamon, D. Carrillo, C. Manzur, New J. Chem. 31 (2007) 1815;

(c) S. Celedon, M. Fuentealba, T. Roisnel, J.-R. Hamon, D. Carrillo, C. Manzur, Inorg. Chim. Acta 390 (2012) 184.

[7] M.N. Kopylovich, M.J. Gajewska, K.T. Mahmudov, M.V. Kirillova, P.J. Figiel, M.F.C. Guedes da Silva, B. Gil-Hernández, J. Sanchiz, A.J.L. Pombeiro, New J. Chem. 36 (2012) 1646.

[8] (a) D. Kalaitzakis, J.D. Rozzell, I. Smonou, S. Kambourakis, Adv. Synth. Catal. 348 (2006) 1958;

(b) Z.N. Li, X.M. Liu, Z. Zheng, H.L. Chen, X.W. Han, Chin. Chem. Lett. 11 (2000) 259. 
[9] (a) C.M. Zakaria, C.A. Morrison, D. McAndrew, W. Bell, C. Glidewell, J. Organomet. Chem. 485 (1995) 201;

(b) A. González, C. López, X. Solans, M. Font-Bardía, E. Molins, J. Organomet. Chem. 693 (2008) 2119;

(c) E. I. Klimova, T. Klimova, J. M. Méndez Stivalet, C. Alvarez Toledano, R. Alfredo Toscano, S. Hernández Ortega, L. Ruíz Ramírez, L. V. Bakinovsky, M. Martínez García, Eur. J. Org. Chem. (2004) 1714.

[10] P.G. Cozzi, L. Zoli, Angew. Chem. Int. Ed. 47 (2008) 4162.

[11] X. Xu, R. Jiang, X. Zhou, Y. Liu, S. Ji, Y. Zhang, Tetrahedron 65 (2009) 877.

[12] V. Nair, L. Balagopal, R. Rajan, J. Mathew, Acc. Chem. Res. 37 (2004) 21.

[13] (a) B. Giese, Radicals in Organic Synthesis: Formation of carbon-carbon bonds, Pergamon: Oxford, 1986.

(b) M. Ramaiah, Tetrahedron 43 (1987) 3541.

[14] V. Nair, A. Deepthi, Chem. Rev. 107 (2007) 1862.

[15] (a) A. Trujillo, S. Sinbandhit, L. Toupet, D. Carrillo, C. Manzur, J.-R. Hamon, J. Inorg. Organomet. Polym. Mater. 18 (2008) 81;

(b) A. Trujillo, M. Fuentealba, D. Carrillo, C. Manzur, J.-R. Hamon, J. Organomet. Chem. 694 (2009) 1435;

(c) A. Trujillo, M. Fuentealba, D. Carrillo, C. Manzur, I. Ledoux-Rak, J.-R. Hamon, J.-Y. Saillard, Inorg. Chem. 49 (2010) 2750.

[16] B. Yucel, B. Sanli, H. Soylemez, H. Akbulut, J. Organomet. Chem. 704 (2012) 49.

[17] V.V. Popic, S.M. Korneev, V.A. Nikolaev, I.K. Korobitsyna, Synthesis (1991) 195.

[18] A. Altomare, M.C. Burla, M. Camalli, G. Cascarano, C. Giacovazzo, A. Guagliardi, A.G.G. Moliterni, G. Polidori, R. Spagna, J. Appl. Crystallogr. 32 (1999) 115.

[19] G.M. Sheldrick, Acta Crystallogr. A64 (2008) 112.

[20] L.J. Farrugia, J. Appl. Crystallogr. 32 (1999) 837.

[21] O.V. Dolomanov, L.J. Bourhis, R.J. Gildea, J.A.K. Howard, H. Puschmann, J. Appl. Crystallogr. 42 (2009) 339.

[22] A.N. Nesmeyanov, E.G. Perevalova, S.P. Gubin, K.I. Granberg, A.G. Kozlovsky, Tetrahedron Lett. 7 (1966) 2381.

[23] J.D. Dunitz, L.E. Orgel, A. Rich, Acta Crystallogr. 9 (1956) 373.

[24] (a) F.H. Allen, O. Kennard, D.G. Watson, L. Brammer, A.G. Orpen, R. Taylor, J. Chem. Soc., Perkin Trans. (1987) S1; 
(b) A.G. Orpen, L. Brammer, F.H. Allen, D. Kennard, D.G. Watson, R. Taylor, J. Chem. Soc., Dalton Trans. (1989) S1.

[25] G. Ferguson, C. Glidewell, C.M. Zakaria, Acta Crystallogr. C50 (1994) 1673.

[26] (a) E. Gyepes, F. Hanic, Cryst. Struct. Commun., 4 (1975) 229;

(b) K. Sato, M. Iwai, H. Sano, M. Konno, Bull. Chem. Soc. Jpn. 57 (1984) 634;

(c) J.C. Barnes, W. Bell, C. Glidewell, R.A. Howie, J. Organomet. Chem. 385 (1990) 369.

[27] N.G. Connelly, W.E. Geiger, Chem. Rev. 96 (1996) 877. 